\title{
Fermented soshiho-tang with Lactobacillus plantarum enhances the antiproliferative activity in vascular smooth muscle cell
}

\author{
Jung-Jin Lee ${ }^{1}$, Hyeeun Kwon', Ji-Hye Lee ${ }^{1}$, Dong-Gun Kim', Sang-Hyuk Jung ${ }^{2}$ and Jin Yeul Ma*
}

\begin{abstract}
Background: Soshiho-tang (SST) is a traditional medicine widely used for the treatment of chronic hepatitis. SST has been shown to confer a variety of pharmacological activities, including prevention of hepatotoxicity, promotion of liver regeneration, and modulation of liver fibrosis. In this study, we investigated the antiproliferative activity of native and fermented (FSST) formulations of SST in vascular smooth muscle cells (VSMCs) and examined the potential underlying mechanisms driving these effects.

Methods: SST, along with preparations fermented with Lactobacillus plantarum KFRI-144 (S-A144), L. amylophilus KFRI-161 (S-A161) and L. bulgaricus KFRI-344 (S-A344), were investigated to determine their effects on the proliferation and viability of VSMCs, along with the signalling pathways underlying these effects.

Results: S-A144 exhibited a strong, dose-dependent inhibition of VSMC proliferation relative to untreated controls, but the others did not affect. In addition, S-A144 significantly decreased the phosphorylation of Akt and PLCY1 in a dose-dependent manner and induced cell cycle arrest at the $G_{0} / G_{1}$ phase characterised by decreased expression of CDKs, cyclins and PCNA.

Conclusions: The findings suggest that S-A144 exhibit enhanced inhibition of PDGF-BB-induced VSMC proliferation comparison to S-AOR through the suppression of cell cycle progression and expression of cell cycle-related proteins, along with the downregulation of Akt phosphorylation.
\end{abstract}

Keywords: Soshiho-tang, Fermentation, Vascular smooth muscle cells, Antiproliferative effect

\section{Background}

Abnormal proliferation and migration of vascular smooth muscle cells (VSMCs) are key events in the pathogenesis of vascular proliferative diseases, such as atherosclerosis and restenosis [1-3]. Following vascular injury, abnormal VSMCs transition to a proliferative phenotype characterised by increased expression of cell cycle and proliferation genes [4]. The cell cycle is a common point of convergence for the mitogenic signalling cascades, which consists of four distinct sequential phases $\left(G_{0} / G_{1}, S, G_{2}\right.$ and $\mathrm{M}$ ). Major check points are controlled by multiple protein kinases, such as cyclin component and a catalytic cyclin-dependent kinase (CDK) $[4,5]$.

\footnotetext{
* Correspondence: jyma@kiom.re.kr

'Korean Medicine (KM)-Based Herbal Drug Development Group, Korea Institute of Oriental Medicine, 1672 Yuseong-daero, Yuseong-gu, Daejeon 305-811, Republic of Korea

Full list of author information is available at the end of the article
}

One of the principal regulators of migration and subsequent proliferation in VSMCs is platelet-derived growth factor (PDGF)-BB, which is secreted by VSMCs and endothelial cells following injury [6-8]. Signalling through the PDGF receptor is mediated through interactions with multiple SH2 domains including phospholipase-C (PLC) $\gamma 1$, phosphatidylinositol 3-kinase (PI3K) and Ras/ Raf-1 [9]. PDGF-BB activates the extracellular-regulated kinases (ERK) via Ras/Raf-1, and Akt via PI3K [10,11], triggering downstream signal transduction and cell cycle progression [12,13]. As ERK1/2 and Akt are the major signal transduction proteins involved in the regulation of proliferation and differentiation [14-16], these pathways are important for the development of vascular disease by VSMCs.

Soshiho-tang (SST) is a traditional medicine widely used for the treatment of chronic hepatitis $[17,18]$. SST

\section{Biomed Central}


has been shown to confer a variety of pharmacological activities, including prevention of hepatotoxicity, promotion of liver regeneration and modulation of liver fibrosis [19-21]. However, the antiproliferative activity of SST in VSMCs thus far has not been explored.

Fermentation with pharmaceutical fungal species has been shown to improve the therapeutic effect of some herbal medicines [22-24]. Fermentation has been suggested to increase the concentration of bioactive components, such as antioxidants, reduce the risk of ethanolinduced liver toxicity and improve the anti-inflammatory activity of many compounds $[2,23,25]$. In this study, we investigated the antiproliferative activity of SST in VSMCs in both fermented (FSST) and unfermented forms.

\section{Methods}

\section{Materials}

Ginseng Radix, Pinellia Tuber, Bupleurum Root, Glycyrrhizae Radix et Rhizoma, Scutellaria Root, Zingiberis Rhizoma Crudus and Zizyphi Fructus were purchased from Yeongcheon herbal market (Yeongcheon, Korea). Identification of all plant material was confirmed by Prof. Ki Hwan Bae of the College of Pharmacy, Chungnam National University (Daejeon, Korea), and all voucher specimens were deposited in the herbal bank in Korea Institute of Oriental Medicine (KIOM, Daejeon, Korea). Dulbecco's Modified Eagle Medium (DMEM) was purchased from Lonza (Wakersville, MD, USA). Fetal bovine serum (FBS) and phosphate-buffered saline (PBS) were purchased from Hyclone (Longan, UT, USA). Penicillin/streptomycin and trypsin/EDTA were purchased from Gibco (Grand Island, NY, USA). Antiphospho-ERK1/2, anti-phospho-Akt, anti-phospho-PLC $\gamma 1$, anti-ERK1/2, anti-Akt, anti-PLC 1 , anti-CDK2, anti-CDK4, anti-cyclin $\mathrm{D}_{1}$, anti-cyclin $\mathrm{E}_{1}$ and anti- $\beta$-actin antibodies were from Cell Signaling Technology Inc. (Beverly, MA). Anti- phospho-proliferating cell nuclear antigen (PCNA) was purchased from Abfrontier (Seoul, Korea). PDGF-BB was obtained from Upstate Biotechnology (Lake Placid, NY, USA). Cell Counting Kit-8 (CCK-8) was purchased from Dojindo Molecular Technologies (Rockville, MD, USA). Other chemicals were of analytical grade.

\section{Preparation of SST extract}

SST was prepared according to previously reported method [19]. Briefly, $1674.5 \mathrm{~g}$ medicinal herbal drug, including Bupleurum Root 600 g, Glycyrrhizae Radix et Rhizoma 100 g, Ginseng Radix 200 g, Pinellia Tuber 200 g, Scutellaria Root $400 \mathrm{~g}$, Zingiberis Rhizoma Crudus $74.5 \mathrm{~g}$ and Zizyphi Fructus $100 \mathrm{~g}$, was decocted with $16.745 \mathrm{~L}$ of boiling water in stainless oven for $3 \mathrm{~h}$ at $115^{\circ} \mathrm{C}$ using a Gyeongseo Extractor Cosmos-600 (Incheon, Korea), and then the decoction was filtered using standard testing sieves (150 $\mu \mathrm{m}$; Retsch, Haan, Germany). Then, the filtrate was lyophilized and stored in desiccators at $4^{\circ} \mathrm{C}$. For the fermentation of SST extract, the freeze-dried extract powder was then dissolved in distilled water, and kept at $4^{\circ} \mathrm{C}$. In addition, for the experiment of this study, the freeze-dried extract powder was then dissolved in $50 \%$ dimethyl sulfoxide (DMSO, v/v with phosphate buffered saline) and filtered (pore size, $0.2 \mu \mathrm{m}$ ), and kept at $4^{\circ} \mathrm{C}(\mathrm{S}-\mathrm{OR})$.

\section{Fermentation of SST extract}

In this study, Lactobacillus plantarum KFRI-144 (S-A144), Lactobacillus amylophilus KFRI-161 (S-A161) and Lactobacillus bulgaricus KFRI-344 (S-A344) used with the fermentation of SST was derived from Korea Food Research Institute (KFRI, Seongnam-si, Korea). Two successive transfers of the test organisms in MRS broth $(10 \mathrm{~g} / \mathrm{L}$ peptone, $10 \mathrm{~g} / \mathrm{L}$ beef extract, $5 \mathrm{~g} / \mathrm{L}$ yeast extract, $20 \mathrm{~g} / \mathrm{L}$ glucose, $1 \mathrm{~mL} / \mathrm{L}$ Tween 80, $2 \mathrm{~g} / \mathrm{L} \mathrm{K}_{2} \mathrm{HPO}_{4}, 5 \mathrm{~g} / \mathrm{L}$ sodium acetate, $2 \mathrm{~g} / \mathrm{L}$ triammonium citrate, $0.2 \mathrm{~g} / \mathrm{L} \mathrm{MgSO}_{4} \cdot 7 \mathrm{H}_{2} \mathrm{O}$, $0.2 \mathrm{~g} / \mathrm{L} \mathrm{MnSO} 4.4 \mathrm{H}_{2} \mathrm{O}, \mathrm{pH}$ 6.2-6.6) for lactobacilli culture at $37^{\circ} \mathrm{C}$ for $24 \mathrm{~h}$, and then the activated cultures were again inoculated into broth. It was properly diluted to obtain an initial population of $1-5 \times 10^{6} \mathrm{CFU} / \mathrm{mL}$ and served as the inoculum. The viable cell count of strain was determined in duplicate by using the pour-plate method on MRS agar. In fermentation process, $5 \mathrm{~mL}$ of SST was inoculated with $0.05 \mathrm{~mL}$ of the inocula as above, and then this was incubated at $37^{\circ} \mathrm{C}$ for $48 \mathrm{~h}$. At an interval of $24 \mathrm{~h}$, fermented SSTs were collected and were analyzed $\mathrm{pH}$. Lactobacillus plantarum KFRI-144 (S-A144), Lactobacillus amylophilus KFRI-161 (S-A161) and Lactobacillus bulgaricus KFRI-344 (S-A344) were selected as the high acid-production using $\mathrm{pH}$ analysis and 1st screening test of antiproliferative activity.

\section{Cell culture}

Rat aortic VSMC were purchased from BioBud (Seongnam, Korea), which was isolated by enzymatic dispersion as previously described [26,27]. VSMC was cultured in DMEM, supplemented with 10\% FBS, $100 \mathrm{IU} / \mathrm{mL}$ penicillin, $100 \mu \mathrm{g} / \mathrm{mL}$ streptomycin, $8 \mathrm{mM} \mathrm{HEPES}$ and $2 \mathrm{mM} \mathrm{L}$-glutamine at $37^{\circ} \mathrm{C}$ in a humidified atmosphere of $95 \%$ air and $5 \% \mathrm{CO}_{2}$ incubator. The purity of VSMC culture was confirmed by immunocytochemical localization of $\alpha$-smooth-muscle actin. The passage number of VSMC used in this experiment was with 5-7.

\section{Cell proliferation assay}

VSMC was measured by both direct counting and nonradioactive colorimetric WST-1 assay (CCK-8, Takara, Japan). For direct cell counting, rat aortic smooth muscle cells were seeded into 12-well culture plates at $4 \times 10^{4}$ cells $/ \mathrm{mL}$, and then cultured in DMEM containing $10 \% \mathrm{FBS}$ at $37^{\circ} \mathrm{C}$ for $24 \mathrm{~h}$. After reaching at $\sim 70 \%$ of 
confluence, the cells were incubated with serum-free medium for $24 \mathrm{~h}$, treated with SST (S-OR) and FSST formulas (S-AOR, S-A144, S-A161, and S-A344) for another $24 \mathrm{~h}$ in newly fresh serum-free medium and stimulated by PDGF-BB $(25 \mathrm{ng} / \mathrm{mL})$. After $24 \mathrm{~h}$ the cells were trypsinized by trypsin-EDTA and counted by using hemocytometer under microscopy. For nonradioactive colorimetric WST-1 assay, all experimental procedures were performed as recommended by manufacturer's instructions, and the results were expressed as percentage of PDGF-BB-stimulated control.

\section{Cell viability assay}

VSMC was seeded into 96 well culture plates at $3 \times 10^{4}$ cells $/ \mathrm{mL}$, and then cultured in DMEM containing $10 \%$ FBS at $37^{\circ} \mathrm{C}$ for $24 \mathrm{~h}$. After reaching at $70 \%$ of confluence, the cells were incubated with serum-free medium for $24 \mathrm{~h}$. The cells were exposed to $500 \mu \mathrm{g} / \mathrm{mL} \mathrm{S}$-A144 or $50 \mu \mathrm{M}$ digitonin as a cytotoxic control at various times. WST-1 reagent was added to the medium, and the cells were incubated for an additional $2 \mathrm{~h}$. The absorbance was measured at $450 \mathrm{~nm}$ using a spectrophotometer.

\section{Cell cycle progression analysis}

The measurement of cell cycle progression was performed as previously described $[26,27]$. The assay condition was the same as described in the section of cell proliferation assay. After being stimulated by PDGF-BB $(25 \mathrm{ng} / \mathrm{mL})$ for $24 \mathrm{~h}$, cells were trypsinized and centrifuged at $1,500 \times g$ for $7 \mathrm{~min}$. The centrifuged pellets were suspended in $1 \mathrm{~mL}$ of $1 \times$ PBS, washed twice, and fixed with $70 \%$ ethanol for $48 \mathrm{~h}$. The fixed cells were briefly vortexed and centrifuged at $15,000 \times g$ for $5 \mathrm{~min}$. The ethanol was discarded and the pellets were stained with $500 \mu \mathrm{L}$ propidium iodide (PI) solution $(50 \mu \mathrm{g} / \mathrm{mL}$ PI in sample buffer containing $100 \mu \mathrm{g} / \mathrm{mL}$ of RNase A). Before flow cytometry analysis, each sample was incubated at room temperature for $1 \mathrm{~h}$. The PI-DNA complex in each cell nucleus was measured with FACScalibur (Becton \& Dickinson Co.). The individual nuclear DNA content was reflected by fluorescence intensity of incorporated PI. The rate of the cell cycle within $G_{0} / G_{1}, S$ and $G_{2} / M$ phase was determined by analysis with Modfit LT software.

\section{Immunoblotting assay}

Immunoblotting assay was performed as previously described [26,27]. Rat aortic smooth muscle cells were stimulated with PDGF-BB ( $25 \mathrm{ng} / \mathrm{mL}$ ) for $5 \mathrm{~min}$ for ERK 1/2 and PLCY1, 15 min for Akt phosphorylation assays. For the assay of CDK2, CDK4, cyclin $\mathrm{D}_{1}$, cyclin $\mathrm{E}_{1}$ and PCNA expressions, VSMC were stimulated by PDGF-BB $(25 \mathrm{ng} / \mathrm{mL})$ for $24 \mathrm{~h}$. The detected proteins were normalized by $\beta$-actin or respective total proteins, respectively. The intensities of bands were quantified using a Scion-Image for Window Program (Scion Corporation, MA).

\section{Statistical analysis}

Data were expressed as means \pm S.E.M. Statistical comparisons were conducted via one-way analysis of variance (ANOVA) followed by Dunnett's test to determine which groups differed significantly from the control group. Comparison of the two groups was conducted via an unpaired Student's $t$ test (GraphPad, San Diego, USA). A p value of $<0.05$ was considered significant.

\section{Results}

\section{Effects of SST and FSST on VSMC proliferation}

To compare the antiproliferative effects of SST formulas on VSMCs, we performed colourimetric WST-1 and cell counting assays. Among the FSST formulas, SST fermented with Lactobacillus plantarum KFRI-144 (S-A144) exhibited the strongest inhibition of PDGFBB-induced proliferation in VSMCs (Figure 1A). This effect was stronger than that of S-AOR, a sterilised formulation of SST.

In cell counting assays, treatment of VSMCs with $25 \mathrm{ng} / \mathrm{mL}$ PDGF-BB significantly increased cell proliferation after $24 \mathrm{~h}$ (Figure 1A). Pretreatment of cells with $500 \mu \mathrm{g} / \mathrm{mL}$ S-A144 significantly reduced VSMC proliferation to $4.0 \pm 0.3 \times 10^{4}$ cells/well (Figure 1B). Further analysis of compound S-A144 alone showed a concentration-dependent inhibition of VSMC proliferation (Figure 2A), with cell numbers decreased significantly to $8.9 \pm 0.5(100 \mu \mathrm{g} / \mathrm{mL}), 6.8 \pm 0.4(300 \mu \mathrm{g} / \mathrm{mL})$ and $5.7 \pm 0.4 \times 10^{4}$ cells $/$ well $(500 \mu \mathrm{g} / \mathrm{mL})$ compared with $9.4 \pm 0.4 \times 10^{4}$ cells/well for PDGF-BB treatment controls (Figure 2B). These antiproliferative effects were not due to enhanced cytotoxicity, as even the highest concentration of S-A144 $(500 \mu \mathrm{g} / \mathrm{mL})$ exhibited no cytotoxicity in serum-free medium (Figure 2C). In contrast, $50 \mu \mathrm{g} / \mathrm{mL}$ digitonin as a positive cytotoxic control was cytotoxic $[26,28]$.

\section{Effects of S-A144 on ERK1/2, Akt and PLC 1 activation}

Our previous study demonstrated that early signal, such as Akt, ERK1/2 and PLC 1 phosphorylation, is important signal transduction in hyper-proliferation of VSMCs $[26,29]$. Hence, to investigate the role of early signalling events in the antiproliferative activity of S-A144, phosphorylation of Akt, ERK1/2 and PLC 1 was measured in VSMCs following stimulation with PDGF-BB. As shown Figure 3, S-A144 significantly decreased the phosphorylation of Akt and PLC $\gamma 1$ in a concentration-dependent manner, but ERK1/2 phosphorylation was unaffected. The inhibitory effect of S-A144 on Akt phosphorylation 


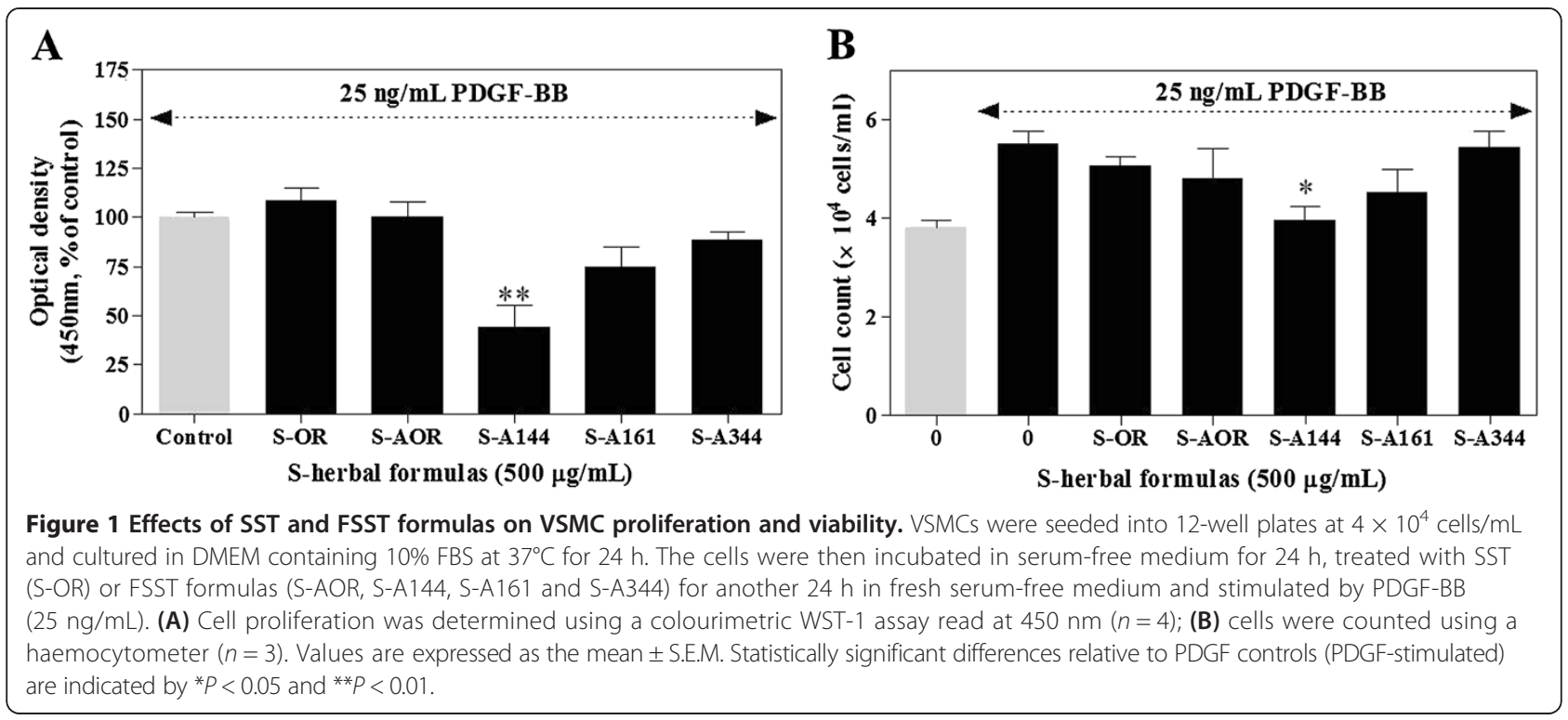

A
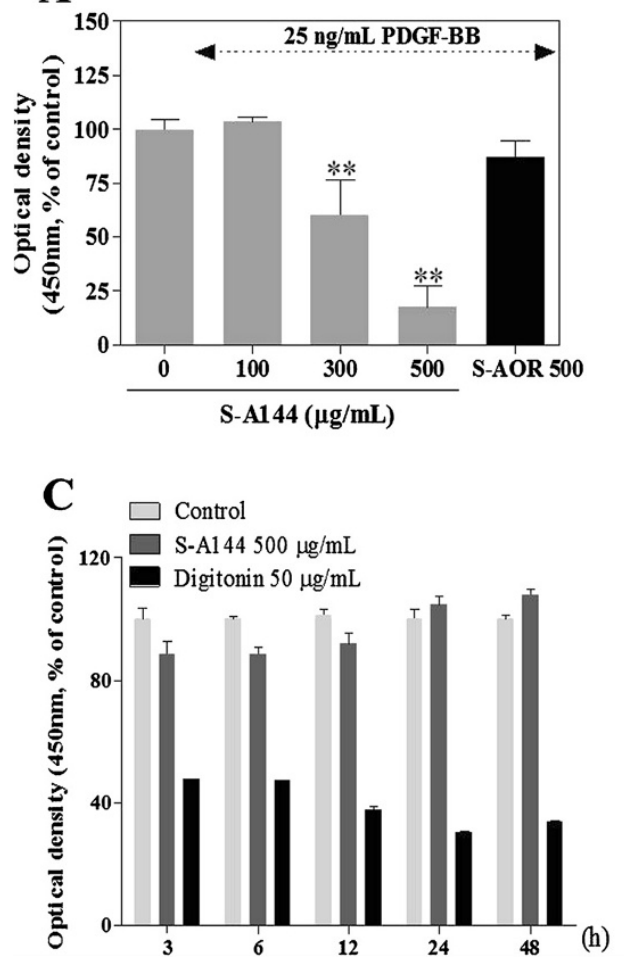

B

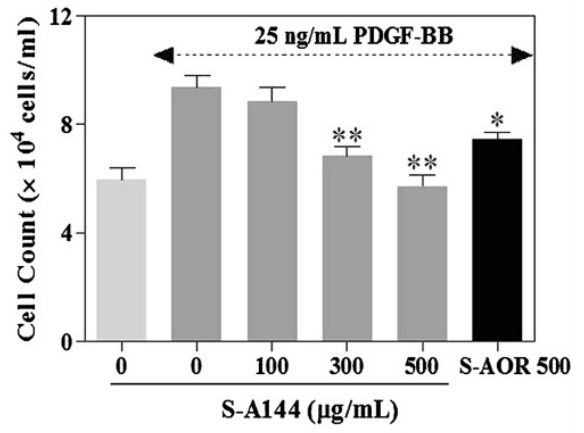

Figure 2 Effect of S-A144 on VSMC proliferation and viability. VSMCs cultured in serum-free medium were stimulated with 25 ng/mL PDGF-BB for $24 \mathrm{~h}$, and the effect of various concentrations of S-A 144 (100-500 $\mu \mathrm{g} / \mathrm{mL})$ or S-AOR (500 $\mu \mathrm{g} / \mathrm{mL})$ on cell proliferation and viability was measured. (A) Cell proliferation was determined using a colourimetric WST-1 assay read at $450 \mathrm{~nm}(n=4)$. (B) Cells were counted using a haemocytometer $(n=3)$. (C) VSMCs were treated with $500 \mathrm{ng} / \mathrm{mL}$ S-A144 for 24 h; cell viability was determined using a WST-1 assay read at $450 \mathrm{~nm}(n=4)$. Digitonin was used as a positive cytotoxic control. Values are expressed as mean \pm S.E.M. Statistically significant differences relative to PDGF controls (PDGF-stimulated) are indicated by ${ }^{*} P<0.05$ and ${ }^{* *} P<0.01$. 


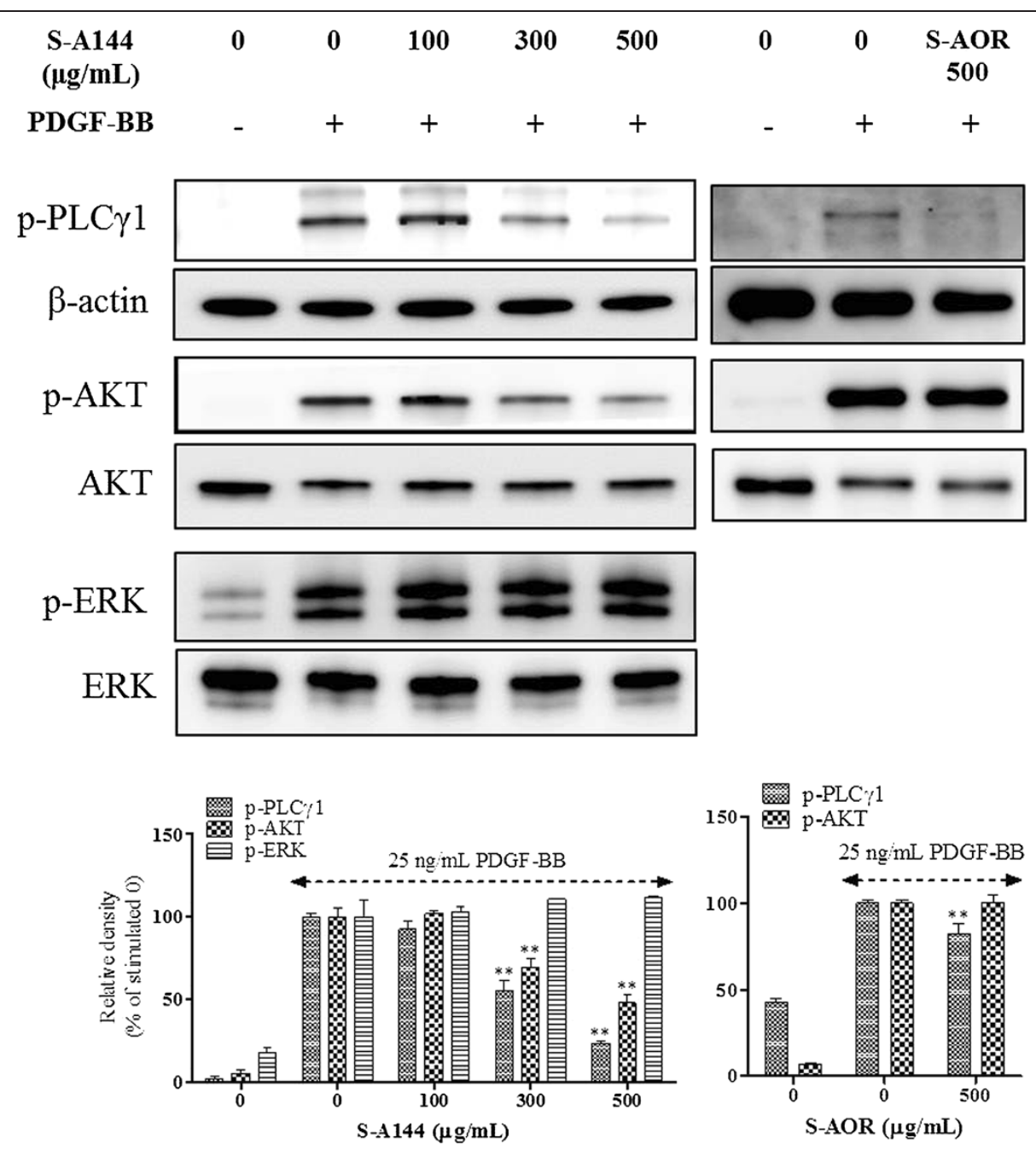

Figure 3 Effects of S-A144 on the PDGF-induced activation of ERK1/2, Akt and PLC 1 1. Quiescent VSMCs cultured in serum-free medium were stimulated with $25 \mathrm{ng} / \mathrm{mL}$ PDGF-BB, followed by the addition of various concentrations of S-A144 (100-500 $\mu \mathrm{g} / \mathrm{mL})$ or S-AOR (500 $\mu \mathrm{g} / \mathrm{mL})$ to determine the effect on phosphorylation of ERK1/2, Akt and PLC 1 , as measured by SDS-PAGE and immunoblotting. Total ERK1/2, Akt or $\beta$-actin were used for normalisation. Data are representative of three independent experiments. Values are expressed as the mean \pm S.E.M. Statistically significant differences relative to PDGF controls (PDGF-stimulated) are indicated by ${ }^{* *} P<0.01$.

was significantly greater than that seen with S-AOR $(48.0 \pm 4.7 \%$ and $100.2 \pm 4.2 \%$, respectively). These results indicate that the antiproliferative action of S-A144 derived by inhibition of Akt and PLC 11 phosphorylation, the activity enhancement of S-A144 comparison with SAOR was due to the suppression of PI3K-mediated signalling pathway.

\section{Effect of S-A144 on cell cycle progression}

We next examined the effects of PDGF-BB and S-A144 on cell cycle progression. The addition of PDGF-BB to VSMCs cultured in serum-free media resulted in considerable synchronisation in the $G_{0} / G_{1}$ phase $(74.2 \pm 1.8 \%)$; another $17.0 \pm 2.0 \%$ of the cells were in $\mathrm{S}$ phase (Figure $4 \mathrm{~A}$ ). Following treatment with S-A144, the percentage of cells in $G_{0} / G_{1}$ phase increased in a dose dependent manner, ranging from $83.3 \pm 1.9(100 \mu \mathrm{g} / \mathrm{mL})$ to $92.9 \pm$ $0.8 \%(500 \mu \mathrm{g} / \mathrm{mL})$, respectively. Taken together, these results show that the antiproliferative effects of S-A144 result in the arrest of cells in $G_{0} / G_{1}$ phase through the inhibition of specific signalling pathways, including Akt and PLC $\gamma 1$.

Effect of S-A144 on cell cycle-related protein expression Cell cycle progression is strictly regulated through the expression of cell cycle-related proteins, such as CDK2, CDK4, cyclin D1, cyclin E1 and PCNA [5]. To demonstrate the mechanism of S-A144-induced the arrest of cell cycle, we investigated the effect of S-A144 on CDK2, CDK4, cyclin D1 and cyclin E1 expression. The result shown in Figure 4B represented that S-A144 inhibited the expression of CDK 2, CDK4 and cyclin 


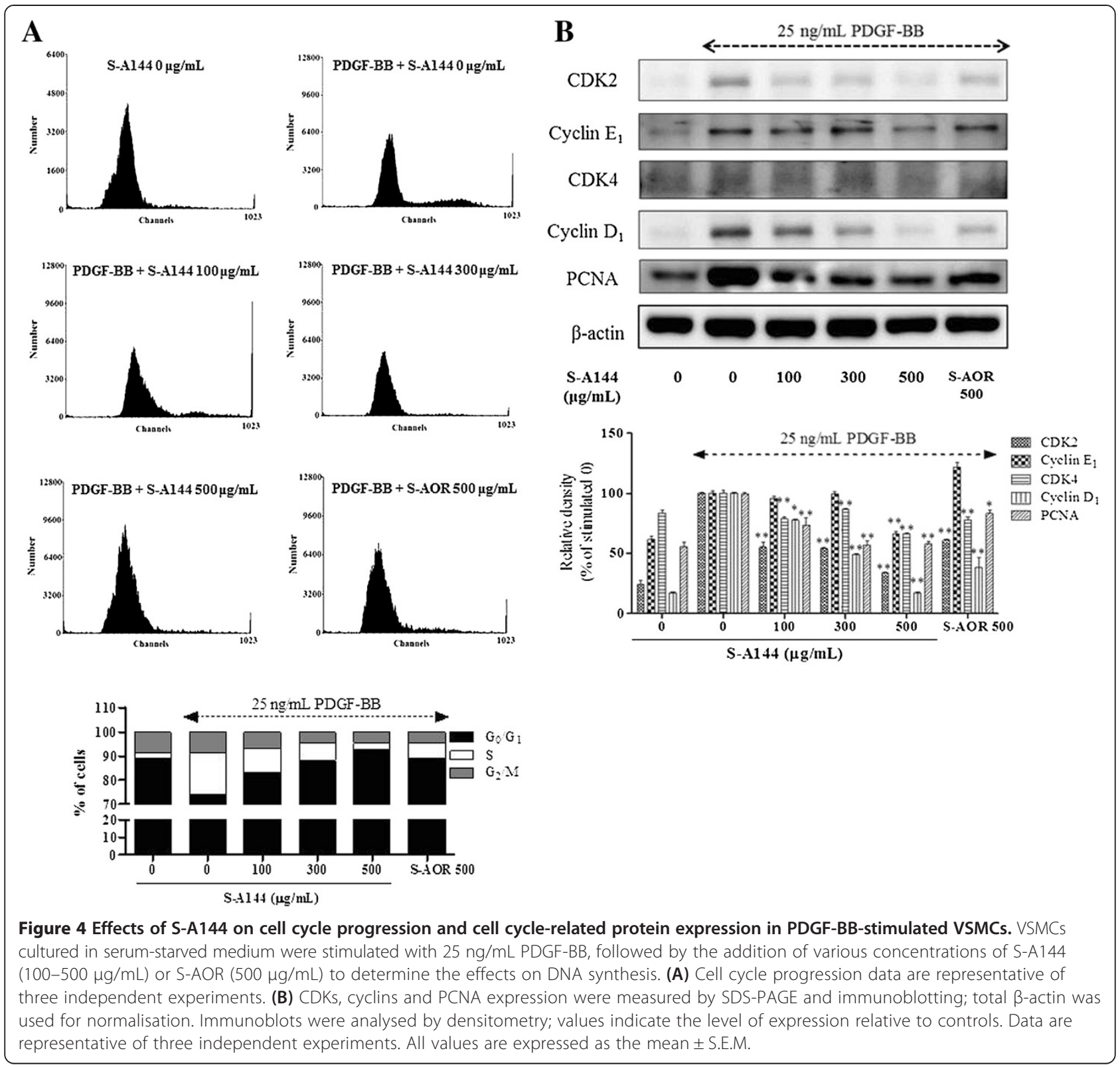

$D_{1}$ in a concentration-dependent manner. In the effect of S-A144 on cyclin $E_{1}$ expression, S-A144 only inhibited at a concentration of $500 \mu \mathrm{g} / \mathrm{mL}$, however, S-AOR at the same concentration did not affect. Moreover, in other cell cycle-related protein expression, S-A144 was greater than S-AOR. In addition, expression of PCNA, synthesised as a phosphorylated retinoblastoma (Rb) protein-mediated gene product in early $G_{0} / G_{1}$ and $S$ phase, was also inhibited by S-A144 (Figure 4B). This effect was significantly greater for S-A144 than S-AOR, suggesting that the enhanced antiproliferative effects of S-A144 compared to S-AOR occur via arrest in $\mathrm{G}_{0} / \mathrm{G}_{1}$ phase through inhibition of cell cycle-related protein expression.

\section{Discussion}

This study demonstrated that fermentation of SST enhanced the antiproliferative effects of this compound on VSMCs. This enhanced effect occurred via arrest in the $G_{0} / G_{1}$ phase through inhibition of Akt phosphorylation and cell cycle-related protein expression.

Cardiovascular disease is a complex condition stemming from a variety of physiological processes, including VSMC proliferation, hypertension and inflammation [30,31]. Among these causes, VSMC proliferation plays a central role in the pathogenesis of atherosclerosis and restenosis after vascular injury, and possibly in the development of hypertension $[4,32]$. For the clinical application, research on the VSMC proliferation has been 
report in connection with restenosis, such as the development of bio-stent, the suppression of neointima formation after balloon injury, and the importance of VSMC proliferation after vascular injury and stenting [33-35]. Controlling VSMC proliferation may therefore be important for the treatment of cardiovascular disorder and atherosclerosis [26,36].

Fermentation has recently been shown to confer beneficial effects on VSMC proliferation, including inhibition of proliferation and migration of SMCs by Chungtaejeon, a Korean fermented tea, and the vasoprotective effects mediated by the nonalcoholic constituents of red wine $[37,38]$. To identify the mechanism by which fermentation enhanced the antiproliferative activity of SST, we investigated a variety of SST fermentation formulas including eight strains of Lactobacillus and two strains of Bifidobacterium (data not shown) compared with S-AOR, a sterilised formulation of SST. From these preliminary studies, we selected three strains of Lactobacillus that exhibited the strongest effect on SST antiproliferative activity. In Figure 1, we describe several SST fermentation formulas, with S-A144 exhibiting the strongest antiproliferative effect on VSMCs.

S-A144 significantly inhibited PDGF-BB-induced VSMC proliferation in a dose-dependent manner (Figure 2). Moreover, Akt and PLC $\gamma 1$ phosphorylation were identified as possible molecular mechanisms by which S-A144 inhibited cell proliferation.

PDGF-mediated cellular proliferation is a highly regulated process involving PLC $\gamma 1$, PI3K and mitogen activated protein (MAP) kinase activation [39,40]. PLC 1 phosphorylation modulates the downstream signal transduction of a variety of growth factors, including PDGF [9]. S-AOR significantly inhibited PDGF-BB-induced PLC $\gamma 1$ phosphorylation, but did not inhibit AKT phosphorylation. These data therefore indicate that PLC 1 may be a target of S-AOR in VSMCs. In contrast, S-A144 showed a greater inhibitory effect on Akt phosphorylation than S-AOR (Figure 3), indicating that fermentationrelated products were modulating Akt activity.

Akt, a serine/threonine protein kinase, is phosphorylated through the PI3K pathway and is important in regulating cell cycle progression [11], which is modulated by regulatory factors, including cyclin and CDKs, with $\mathrm{pRb}$ considered an important inhibitor of proliferation $[5,10]$.

VSMC proliferation is modulated primarily by regulation of the cell cycle, S-A144 inhibited cell cycle progression by arresting cells in $G_{0} / G_{1}$ phase (Figure $4 A$ ). This tightly regulated temporal progression is controlled by the sequential activation of CDKs and their subunits, cyclins that phosphorylate the Rb protein. S-A144 also inhibited the cell cycle-related protein involving CDKs, cyclins, and PCNA expression (Figure 4B), which is synthesised as a pRb phosphorylation-mediated gene product required for the $G_{0} / G_{1}$ to $S$ phase transition [41], consistent with the effects seen on cell cycle progression. These effects were greater for S-A144 than SAOR, suggesting that S-A144 may exhibit enhanced inhibition of cell cycle progression and expression of cell cycle-related proteins via the inhibition of Akt phosphorylation.

\section{Conclusions}

This study demonstrates that S-A144, an SST formulation fermented with L. plantarum, exhibit enhanced inhibition of PDGF-BB-induced VSMC proliferation comparison to $\mathrm{S}$-AOR through the induction of cell cycle arrest at the $\mathrm{G}_{0} / \mathrm{G}_{1}$ phase and inhibition of CDKs, cyclins and PCNA expression. This inhibition may be mediated through a downregulation of Akt phosphorylation. Together, these data suggest that S-A144 may be useful in the prevention of atherosclerosis and restenosis.

\section{Abbreviations}

PI3K: Phosphatidylinositol 3'-kinase; CCK-8: Cell counting kit-8;

CDK: Cyclin-dependent kinase; DMEM: Dulbecco's modified Eagle's medium; DMSO: Dimethyl sulphoxide; ERK: Extracellular signal-regulated kinase; FBS: Foetal bovine serum; PBS: Phosphate-buffered saline;

PCNA: Phospho-proliferating cell nuclear antigen; PDGF: Platelet-derived growth factor; PLC 1 1: Phospholipase C- $\gamma 1$; SDS-PAGE: Sodium dodecyl sulphate-polyacrylamide gel electrophoresis; SH: Soshiho-tang; VSMC: Vascular smooth muscle cells.

\section{Competing interests}

The authors declare that they have no competing interests.

\section{Authors' contributions}

$J J \mathrm{~L}$ and JYM participated in the design of the study; JJL, HK, JHL, DGK and SHJ performed all experiments; JJL and JYM analysed the data and wrote the paper. All authors read and approved the final manuscript prior to submission.

\section{Acknowledgements}

This work was supported by grant K14050 awarded to the Korea Institute of Oriental Medicine (KIOM) from the Ministry of Education, Science and Technology (MEST), Republic of Korea.

\section{Author details}

${ }^{1}$ Korean Medicine (KM)-Based Herbal Drug Development Group, Korea Institute of Oriental Medicine, 1672 Yuseong-daero, Yuseong-gu, Daejeon 305-811, Republic of Korea. ${ }^{2}$ Department of Pharmacology, Chungnam National University, College of Pharmacy, Daejeon 305-764, Republic of Korea.

Received: 21 August 2013 Accepted: 24 February 2014 Published: 28 February 2014

\section{References}

1. Luscher TF, Steffel J, Eberli FR, Joner M, Nakazawa G, Tanner FC, Virmani R: Drug-eluting stent and coronary thrombosis: biological mechanisms and clinical implications. Circulation 2007, 115(8):1051-1058.

2. Owens GK, Kumar MS, Wamhoff BR: Molecular regulation of vascular smooth muscle cell differentiation in development and disease. Physiol Rev 2004, 84(3):767-801.

3. Faxon DP, Fuster V, Libby P, Beckman JA, Hiatt WR, Thompson RW, Topper JN, Annex BH, Rundback JH, Fabunmi RP, Robertson RM, Loscalzo J, American Heart Association: Atherosclerotic Vascular Disease Conference: Writing Group III: pathophysiology. Circulation 2004, 109(21):2617-2625. 
4. Dzau VJ, Braun-Dullaeus RC, Sedding DG: Vascular proliferation and atherosclerosis: new perspectives and therapeutic strategies. Nat Med 2002, 8(11):1249-1256.

5. Braun-Dullaeus RC, Mann MJ, Sedding DG, Sherwood SW, von der Leyen HE, Dzau VJ: Cell cycle-dependent regulation of smooth muscle cell activation. Arterioscler Thromb Vasc Biol 2004, 24(5):845-850.

6. Sachinidis A, Locher R, Hoppe J, Vetter W: The platelet-derived growth factor isomers, PDGF-AA, PDGF-AB and PDGF-BB, induce contraction of vascular smooth muscle cells by different intracellular mechanisms. FEBS Lett 1990, 275(1-2):95-98.

7. Kher N, Marsh JD: Pathobiology of atherosclerosis-a brief review. Semin Thromb Hemost 2004, 30(6):665-672.

8. Schwartz SM: Smooth muscle migration in atherosclerosis and restenosis. J Clin Invest 1997, 100(11 Suppl):S87-S89.

9. Heldin $\mathrm{CH}$, Ostman A, Ronnstrand L: Signal transduction via platelet-derived growth factor receptors. Biochim Biophys Acta 1998, 1378(1):F79-F113.

10. Pearson G, Robinson F, Beers Gibson T, Xu BE, Karandikar M, Berman K, Cobb MH: Mitogen-activated protein (MAP) kinase pathways: regulation and physiological functions. Endocr Rev 2001, 22(2):153-183.

11. Higaki M, Shimokado K: Phosphatidylinositol 3-kinase is required for growth factor-induced amino acid uptake by vascular smooth muscle cells. Arterioscler Thromb Vasc Biol 1999, 19(9):2127-2132.

12. Ahn HY, Hadizadeh KR, Seul C, Yun YP, Vetter $H$, Sachinidis A: Epigallocathechin-3 gallate selectively inhibits the PDGF-BB-induced intracellular signaling transduction pathway in vascular smooth muscle cells and inhibits transformation of sis-transfected NIH 3 T3 fibroblasts and human glioblastoma cells (A172). Mol Biol Cell 1999, 10(4):1093-1104.

13. Blenis J: Signal transduction via the MAP kinases: proceed at your own RSK. Proc Natl Acad Sci U S A 1993, 90(13):5889-5892.

14. Widmann C, Gibson S, Jarpe MB, Johnson GL: Mitogen-activated protein kinase: conservation of a three-kinase module from yeast to human. Physiol Rev 1999, 79(1):143-180

15. Roche S, Koegl M, Courtneidge SA: The phosphatidylinositol 3-kinase alpha is required for DNA synthesis induced by some, but not all, growth factors. Proc Natl Acad Sci U S A 1994, 91(19):9185-9189.

16. Kim TJ, Lee JH, Lee JJ, Yu JY, Hwang BY, Ye SK, Shujuan L, Gao L, Pyo MY, Yun YP: Corynoxeine isolated from the hook of Uncaria rhynchophylla inhibits rat aortic vascular smooth muscle cell proliferation through the blocking of extracellular signal regulated kinase $1 / 2$ phosphorylation. Biol Pharm Bull 2008, 31(11):2073-2078.

17. Daibo A, Yoshida Y, Kitazawa S, Kosaka Y, Bando T, Sudo M: A case of pneumonitis and hepatic injury caused by a herbal drug (sho-saiko-to). Nihon Kyobu Shikkan Gakkai Zasshi 1992, 30(8):1583-1588.

18. Kawasaki A, Mizushima Y, Kunitani H, Kitagawa M, Kobayashi M: A useful diagnostic method for drug-induced pneumonitis: a case report. Am J Chin Med 1994, 22(3-4):329-336.

19. Chen MH, Chen JC, Tsai CC, Wang WC, Chang DC, Tu DG, Hsieh HY: The role of TGF-beta 1 and cytokines in the modulation of liver fibrosis by Sho-saiko-to in rat's bile duct ligated model. J Ethnopharmacol 2005, 97(1):7-13.

20. Ohta Y, Nishida K, Sasaki E, Kongo M, Hayashi T, Nagata M, Ishiguro I: Comparative study of oral and parenteral administration of sho-saiko-to (xiao-chaihu-tang) extract on D-galactosamine-induced liver injury in rats. Am J Chin Med 1997, 25(3-4):333-342.

21. Borchers AT, Sakai S, Henderson GL, Harkey MR, Keen CL, Stern JS, Terasawa K, Gershwin ME: Shosaiko-to and other Kampo (Japanese herbal) medicines: a review of their immunomodulatory activities. J Ethnopharmacol 2000, 73(1-2):1-13.

22. Shim KS, Kim T, Ha H, Cho CW, Kim HS, Seo DH, Ma JY: HwangryunHaedok-Tang Fermented with Lactobacillus casei Suppresses Ovariectomy-Induced Bone Loss. Evid Based Complement Alternat Med 2012, 2012(325791):12.

23. Oh YC, Cho WK, Jeong YH, Im GY, Yang MC, Ma JY: Fermentation improves anti-inflammatory effect of sipjeondaebotang on LPS-stimulated RAW 264.7 cells. Am J Chin Med 2012, 40(4):813-831.

24. Baek MW, Seok SH, Lee HY, Kim DJ, Lee BH, Ahn YT, Lim KS, Huh CS, Park $\mathrm{J}$ : Protective and therapeutic effects of an extract mixture of alder tree, labiate herb, milk thistle green bean-rice bran fermentation, and turnip against ethanol-induced toxicity in the rat. J Vet Sci 2008, 9(1):31-37.
25. Ng CC, Wang CY, Wang YP, Tzeng WS, Shyu YT: Lactic acid bacterial fermentation on the production of functional antioxidant herbal Anoectochilus formosanus Hayata. J Biosci Bioeng 2011, 111(3):289-293.

26. Lee JJ, Yu JY, Zhang WY, Kim TJ, Lim Y, Kwon JS, Kim DW, Myung CS, Yun YP: Inhibitory effect of fenofibrate on neointima hyperplasia via $G(0) / G$ (1) arrest of cell proliferation. Eur J Pharmacol 2011, 650(1):342-349.

27. Kim JH, Jin YR, Park BS, Kim TJ, Kim SY, Lim Y, Hong JT, Yoo HS, Yun YP: Luteolin prevents PDGF-BB-induced proliferation of vascular smooth muscle cells by inhibition of PDGF beta-receptor phosphorylation. Biochem Pharmacol 2005, 69(12):1715-1721.

28. Lee JJ, Yi H, Kim IS, Kim Y, Nhiem NX, Kim YH, Myung CS: (2S)-naringenin from Typha angustata inhibits vascular smooth muscle cell proliferation via a G0/G1 arrest. J Ethnopharmaco/ 2012, 139(3):873-878.

29. Lee JJ, Zhang WY, Yi H, Kim Y, Kim IS, Shen GN, Song GY, Myung CS: Anti-proliferative actions of 2-decylamino-5,8-dimethoxy-1, 4-naphthoquinone in vascular smooth muscle cells. Biochem Biophys Res Commun 2011, 411(1):213-218.

30. Ross R: The pathogenesis of atherosclerosis: a perspective for the 1990s. Nature 1993, 362(6423):801-809.

31. Raines EW, Ross R: Smooth muscle cells and the pathogenesis of the lesions of atherosclerosis. Br Heart J 1993, 69(1 Suppl):S30-S37.

32. Ross R: Mechanisms of atherosclerosis-a review. Adv Nephrol Necker Hosp 1990, 19:79-86.

33. Weinandy S, Rongen L, Schreiber F, Cornelissen C, Flanagan TC, Mahnken A, Gries T, Schmitz-Rode T, Jockenhoevel S: The BioStent: novel concept for a viable stent structure. Tissue Eng Part A 2012, 18(17-18):1818-1826.

34. Hirschberg K, Tarcea V, Pali S, Barnucz E, Gwanmesia PN, Korkmaz S, Radovits T, Loganathan S, Merkely B, Karck M, Szabó G: Cinaciguat prevents neointima formation after arterial injury by decreasing vascular smooth muscle cell migration and proliferation. Int J Cardiol 2013, 167(2):470-477.

35. Curcio A, Torella D, Indolfi C: Mechanisms of smooth muscle cell proliferation and endothelial regeneration after vascular injury and stenting: approach to therapy. Circ J 2011, 75(6):1287-1296.

36. Lee SK, Kim HN, Kang YR, Lee CW, Kim HM, Han DC, Shin J, Bae K, Kwon BM: Obovatol inhibits colorectal cancer growth by inhibiting tumor cell proliferation and inducing apoptosis. Bioorg Med Chem 2008, 16(18):8397-8402.

37. Sparwel J, Vantler M, Caglayan E, Kappert K, Fries JW, Dietrich H, Bohm M, Erdmann E, Rosenkranz S: Differential effects of red and white wines on inhibition of the platelet-derived growth factor receptor: impact of the mash fermentation. Cardiovasc Res 2009, 81(4):758-770.

38. Karki R, Sahi N, Jeon ER, Park YS, Kim DW: Chungtaejeon, a Korean fermented tea, scavenges oxidation and inhibits cytokine induced proliferation and migration of human aortic smooth muscle cells. Plant Foods Hum Nutr 2011, 66(1):27-33.

39. Sachinidis A, Locher R, Vetter W, Tatje D, Hoppe J: Different effects of platelet-derived growth factor isoforms on rat vascular smooth muscle cells. J Biol Chem 1990, 265(18):10238-10243.

40. Kim TJ, Yun YP: Antiproliferative activity of NQ304, a synthetic 1, 4-naphthoquinone, is mediated via the suppressions of the PI3K/ Akt and ERK1/2 signaling pathways in PDGF-BB-stimulated vascular smooth muscle cells. Vascul Pharmacol 2007, 46(1):43-51.

41. Tomita H, Osanai T, Toki T, Maeda N, Murakami R, Chen Z, Yamabe H, Osawa H, Yasujima M, Okumura K: Roxithromycin is an inhibitor of human coronary artery smooth muscle cells proliferation: a potential ability to prevent coronary heart disease. Atherosclerosis 2005, 182(1):87-95.

doi:10.1186/1472-6882-14-78

Cite this article as: Lee et al.: Fermented soshiho-tang with Lactobacillus plantarum enhances the antiproliferative activity in vascular smooth muscle cell. BMC Complementary and Alternative Medicine 2014 14:78. 